\title{
Double Standards: Corporate Media Ideologies and the Attack on a UN Convoy in Syria
}

\author{
László Bernáth*
}

\begin{abstract}
Opinions about the reliability of news media have become largely dichotomised. The two major factions are those who embrace mainstream media and fundamentally trust them, and those who automatically reject mainstream news as propaganda. The aim of this study is to question and critique specifically the former view by pointing out the ideologically charged nature of mainstream news, while, at the same time, distancing itself from the latter extreme as well. The current system of news-making, it will be argued, essentially limits the presentable perspectives to those of the elite and the establishment, and breeds conformism. To demonstrate my points, I will analyse the coverage of the attack on the United Nations aid convoy in Urum al-Kubra on 19 September 2016. The analysis is limited to four major British news outlets. The focus will be on how the media subtly attach credibility to certain sources while discrediting or dismissing other, no less informative ones, based on the ideological favourability of what information they have to share. Discursive strategies of interest are foregrounding and backgrounding, the inclusion and exclusion of information, the embracing and questioning of sources, and the promoting and discrediting of views, etc. The main emphasis will be on the false impression of factuality and the unquestioning acceptance of otherwise highly questionable claims or allegations.
\end{abstract}

Key words: media studies, syria, ideology

Alpen-Adria-Universität Klagenfurt

lbernath@edu.uni-klu.ac.at 


\section{Introduction}

When in May 2016 I was listening to an enlightening talk given by a refugee from Northwestern Syria, I realised how striking the difference was between his account and experiences of the events, and the way they were presented in the Western corporate news media. His introduction of a new perspective into the overwhelmingly homogeneous perception of the situation in the war in Syria was the first time I had become directly confronted with the existence of viewpoints divergent from the takenfor-granted 'truths' of the Western mainstream press. I had it as a first-hand experience of how difficult it is to construct an alternative point of view when the information available is constantly presented from one specific perspective, and with one specific agenda behind it. First and foremost, he refuses to call the conflict a civil war, a point of view which I also adopt, and instead considers it - boldly, yet appropriately - the destruction of Syria. As he argues, it can hardly be considered a civil war when there are fighters from over 80 foreign countries participating in or assisting the fights on the soil of a sovereign nation (Barrett 2014; Shiraz 2016) - not to mention numerous foreign governments arming and funding various warring factions, pursuing their own geopolitical, economic, or ideological agendas.

His talk initiated a desire in me to investigate the issue of the war in Syria and its media coverage, which eventually has born this study. The first section deals with the system of news production in general. Relying heavily on Herman and Chomsky's (1988) 'Propaganda Model', it will be shown that potential news events have to pass several criteria or filters in order to become news in the first place. While the selection of news items is already an ideological process, the content that eventually does 'make it' to the news encounters additional filters, which further exclude alternative points of view or, indeed, whole events. Such a system of news-making, it will be argued, essentially limits the presentable perspectives to, by and large, those of the elite and the establishment, and breeds conformism. To demonstrate my points, in the second section I will analyse the corporate news coverage of the attack on a United Nations aid convoy in Urum al-Kubra on 19 September 2016. Due to spatial limitations, the focus will be specifically on British corporate news media coverage. Therefore, references to, observations about, or judgments of 'corporate media', 'mass media' or 'Western media' here are meant to be understood in the British context, even though it is assumed that the patterns, strategies, and ideologies discussed are, in this case, largely shared by European and North American corporate media in general as well.

It is important to emphasise that this study is not an investigation for the 'truth', nor does it aim at drawing comparisons between Western mainstream media and their adversarial counterparts. Although the object of investigation and critique is British corporate news, it is not intended to disregard, let alone deny, the applicability of the same criticisms to 'enemy media' as well. In addition, this critique does not aim at denigrating the work of journalists themselves. Instead, it asserts that the discrepancies pointed out 
are largely systemic, and thus the perpetuation of these problems does not necessarily require more than simply acting within the confines of the system, even with the best of intentions and journalistic integrity. The overall aim is to critically analyse the attribution of credibility through various discursive strategies to ideologically favourable sources while discrediting unfavourable ones in the British mainstream press.

\section{Beneath the Veil of 'Freedom'}

\subsection{The Political Economy of News Media}

Despite the apparent variety of different news outlets, each of which is eager to trumpet their independence and objectivity, it is essential to realise that the corporate media are devoid neither of owners nor of powerful external actors whose interests must be attended to (Chomsky 1989; Goodall, et al. 1994, 17-18; Herman and Chomsky 1988). As the designation 'corporate media' already suggests, they are owned by large private corporations - a fact whose consequences are rarely given sufficient thought when consuming news. These corporations are no different from regular businesses in the sense that their primary goal is to make a profit. Such profit orientation has a profound, multidirectional impact on the entire process of news production, from the selection of newsworthy items to the final article or report itself (Fowler 1991, 20-22; Lippmann 1922, 126-127; van Dijk 1988b, 120-121).

On the one hand, the operations of news media have to satisfy not only the owners and managers of the corporation itself but, more importantly, also those who provide financial, material, or other contributions, such as advertisers, banks, news agencies, and other sources of information (Herman and Chomsky 1988). As Freedman writes, when one considers the financial, ideological, and regulatory pressures newspapers have to face from "investors, shareholders and government itself, it becomes clear that [... ] spaces for radical content are always going to be very fragile" in "a newspaper whose ultimate responsibility is to make a profit" $(2014,130)$. By shedding a negative light on the activities, products, services, or general operations of these partners, news outlets would risk significant - and permanent - financial losses. Thus, the project could easily end up in a downward spiral where budgetary constraints would lead to decreasing exposure, which, in turn, would result in further financial difficulties. Similarly, if journalists or reporters represent as questionable the validity and reliability of information provided by their regular sources, which they may well be and often are, those sources may perceive it as a threat to their reputation (Herman and Chomsky 1988, 22). As a consequence, newsmakers would have to rely on more costly and slower ways of accessing information, and/or on less established sources with less authority, whereby they would inevitably lose out on the market. Such pressures result in an effective self-censorship, where restrictions are implemented not so much by coercion as rather 
out of fear of offending influential partners (Chomsky 1989, 48). Thus, newsmakers internalise the standards and develop a sense of what is likely to achieve success and appreciation, and what is not (van Dijk 1988b, 120), whereby ideology is concealed and becomes inseparable from perceived professionality.

Corporate media systematically promote a Western elite perspective (van Dijk 1991, 33). The most common and well-regarded informants or interviewees in news reports are authority figures of some kind, such as officials, politicians, executives or managers, military leaders, the police, etc. Thus, news events "are already predefined by public authorities" whose "documents and information are taken $[\ldots]$ to be the definition of the news situation." (van Dijk 1988b, 8) At the same time, their counterparts, such as demonstrators, activists, dissidents, strikers, etc., receive comparatively little, if any, publicity. Even when their voices are heard, they tend to be presented in a negative light and their statements are much more likely to be called into question or discredited, their concerns trivialised. In short, mainstream news is primarily both about and by the elite and authorities, whereby "the 'common sense' of the institutionalized status quo is ingrained in the discourse." (Fowler 1991, 125) It, then, becomes clear that newsworthiness is not judged based primarily on relevance or usefulness for the public (van Dijk 1988b, 122). News items tend to be framed so as to allow only limited space and depth for criticism of the powers that be (Chomsky 1989, 10; ibid., 75). Problems are usually presented as discrepancies within an otherwise well-functioning system rather than as discrepancies of the system per se, since primary informants have a vested interest in maintaining the status quo (Freedman 2014, 138). Therefore, mainstream media rarely challenge the pre-existing, dominant ideologies and stereotypes of a respective society (Lippmann 1922, 84-89), and largely operate as a platform where social hierarchies and inequalities of power are further reproduced (van Dijk 1988b, 87; 1993).

\subsection{The Role of the Public}

The apparent powerlessness of the public notwithstanding, the key to overcoming the manipulative effects of the system lies in the general population as much as in direct participants in the news-making process. What the political economy approach to news media criticism fails to emphasise is that the public is not merely a passive recipient (Freedman 2014, 117; ibid., 123). Herman and Chomsky have little interest in what the population can do, except for a call for activism or direct action in their Conclusion and a brief, rather patronising remark on the detrimental consequences of a "passive, apathetic" population "diverted to consumerism or hatred of the vulnerable" in Chomsky's later work $(2016,56)$. This is where the socio-cognitive approach of Lippmann (1922) and van Dijk (1988a; 1988b), among others, to public opinion and discourse, respectively, comes to complement the political economic critique. There is no doubt that in the current capitalist media structure the vast majority of the population is denied access to participation in public discourse (Freedman 2014, 132; van Dijk 1991, 37-38). Yet as long as the public continues to seek ideological confirmation and comfort in news, 
misinformation, be it systematic or self-imposed, is inevitable in any system (Goodall, et al. 1994, 14). It is true that people, by nature, pay attention "to those facts which support [their system of stereotypes], and [are] diverted from those which contradict it" (Lippmann 1922, 88-89), whereby a stereotype "stamps itself upon the evidence in the very act of securing the evidence.” (ibid., 73) This is true especially when the established in-group ideologies and the perception of the Self and the Other are contradicted (Zima 1989, 349). Yet despite it being a natural human attitude, it can be overcome through awareness, conscious thought, and self-reflection. To be sure, these do not enable people to make objective judgments, but, more importantly, they lead to the treatment of one's codes, views, and ways of perceiving reality in terms of 'particularity' rather than 'universality' (ibid., 56). It is therefore indispensable for the public, as well as journalists and reporters, to leave their comfort zones and be open to engage in controversial topics, and to become receptive to the validity of alternative narratives and points of view.

\section{The Attack on a UN Aid Convoy in Syria: A Case Study}

\subsection{Scope and Approach}

In order to demonstrate my points, I will look at British mainstream media articles available online which feature the case of the attack on a United Nations aid convoy in Urum al-Kubra and the diplomatic and investigative developments succeeding it. I have chosen this specific event for two major reasons: Firstly, the attack itself as well as the investigations following it have received extensive media attention, therefore sufficient material is available to make observations, to establish certain patterns, and to reflect with confidence. Secondly, the case has evoked elongated, and often heated, diplomatic discussions particularly between the United States and Russia, which allows for an analysis of mass media representation of the distinct parties within the framework of the same event. The analysis is limited to four major British news outlets: BBC, The Daily Mail, The Independent, and The Guardian, with occasional references to the Reuters news agency, on which these news organisations heavily rely for information. Thus, the observations made and the conclusions drawn are not restricted to a single news outlet, nor to a particular political leaning, but are demonstrated to be applicable to corporate media at large, regardless of political stance.

The primary concern of this paper is an ideological analysis of news articles. I adopt a critical discourse analytic approach in order to reflect on discursive strategies that implicate ideological bias, without making judgments as to the intentionality of their application. This study is primarily concerned with the critique of the systemic and structural aspects of news-making. Therefore, there is little space dedicated to close textual analysis, even though it is acknowledged that such an approach does provide additional, more 
detailed and, in fact, indispensable insight into the workings of news discourse. Through the example of the aid convoy attack, I intend to demonstrate the ideological influences of the corporate media system, examined in the previous chapter, on the product and, consequently, on the reader. The overall purpose is not so much to complement the articles in question with facts, but rather to reflect on and critique the double standards the mainstream news media apply towards in-group and out-group members, as well as ideologically favourable and unfavourable informants and information.

\subsection{The Case}

In the evening hours of 19 September 2016, a United Nations humanitarian aid convoy was attacked while unloading at the Syrian Arab Red Crescent warehouse in Urum alKubra. In the attack over a dozen people were reportedly killed and 18 of the 31 trucks carrying humanitarian supply were destroyed. According to witnesses, the assault was continuous and lasted for several hours (Chulov and Shaheen 2016). The events resulted in an aggressive finger-pointing mostly between the United States and Russia, who was immediately blamed for the attack. News outlets, which, as of late, show a remarkable obsession with Russia and the U.S. vs. Russia chess game of negotiations, have paid extensive coverage to the occurrences, the aftermath, and the investigations. As it will be demonstrated, Western corporate media have exploited the tragedy in a propagandistic manner by embracing and unquestioningly reinforcing the ideologically favourable narrative, with little factual basis backed up by investigations and evidence.

\subsection{Replacing Evidence with Blind Trust}

The day following the incident, the Pentagon already claimed to know that the attack was a Russian airstrike, and the press unquestioningly embraced the U.S. American narrative. The accusation is based solely on the eye witness accounts of two unnamed U.S. officials in a private interview with Renters, saying that two Russian Sukhoi SU-24 jets were seen at the time of the attack (Stewart and Dalgleish 2016). Yet in no mainstream news article is the reliability of those officials and their 'evidence' questioned. Instead of pointing out the scarcity of proof, the articles covering the event reinforce the credibility of the accusation by featuring it in headlines such as "Russian planes dropped bombs that destroyed UN aid convoy, US officials say” (Borger and Ackerman 2016a); "US claims Russian warplanes bombed Syrian Arab Red Crescent aid convoy and warehouse" (Walker and McKernan 2016); or "Top US officer: Russia bombed Syria humanitarian aid convoy"1 (Robinson and Newton 2016). While the allegation being elevated to a headline position implies certainty, even the 'top US officer' referred to and quoted, General Dunford, starts his official report by saying that "I don't have the facts." (22 September 22 2016, Report, 43) All they know, he says, is what they have heard from

1 The headline has since been changed, but the original one is still retained in the URL. 
the two anonymous eye witnesses, yet he asserts to have "no doubt in my mind that the Russians are responsible." (ibid.) While his admission to being unable to support his suspicion with facts, is not mentioned in any of the articles, his having 'no doubt' is quoted and embraced in all of them. The omission of the disclaimer is particularly consequential because General Dunford's 'unknowing of facts' is the exact opposite of what is expected of him. As a military general, his words have additional weight and authority. Therefore, the public is very likely to read his claims with the presumption that he, as a high-ranking officer, does base his conclusions on some evidence and facts. Consequently, the articles endow the highly questionable U.S. American claims of a definitive Russian airstrike with an unreasonably high truth value.

On the other hand, Western media apply a 'guilty until proven innocent' approach, where Russia and Syria are expected to disprove whatever the West accuses them of regardless of whether there is any evidence to support these accusations to begin with. Russia is repeatedly discredited as only making "sensational claims" and defying rational accusations by the West "despite evidence that its own forces may have been responsible" (Dearden 2016), which, in reality, does not exist. Note the contradictory use of "evidence", which implies absolute certainty, and "may", which marks possibility. What the sentence actually says, in an upside-down manner, is that Russian involvement cannot be excluded nor proved; in short, no one knows what truly happened. According to The Independent, Russians carry out only a "supposed analysis" (ibid.), and "float several alternative scenarios, which were dismissed by experts" (ibid.). Indeed, Russian responsibility of the attack is presented to be so self-evident that the US has "swiftly" (ibid.) arrived at the conclusion Russia was responsible, and counter-arguments have been, again, "swiftly rejected" (ibid.) by experts. It is, however, not once mentioned, let alone questioned, who those experts actually are and what evidence enables them to arrive at such 'swift' conclusions, apart from a self-imposed sense of infallibility, because none has been provided to the public. The only 'argument' is that Russia's theories "[seek] to implicate the Nobel Prize-nominated White Helmets group of rescue volunteers" (ibid.), which can hardly be considered a refutation. The possibility is rejected not by providing evidence, or at least a rational argument, but by suggesting that the White Helmets would never participate in misinformation as nominees for the Nobel Peace Prize - a piece of information which is absolutely irrelevant in this context but seeks to further reinforce the credibility of the group. It must be emphasised, however, that the problem is not the critical attitude towards Russian or Syrian claims but that no such approach is adopted when tackling the claims of 'our' informants.

\subsection{Marginalising Dissent}

While the ideologically favourable narrative is consistently foregrounded and reinforced, its actual fragility receives but marginal attention. The day after the attack, the United Nations issued a statement through spokesman Jens Laerke saying: "We are not in a position to determine whether these were in fact airstrikes. We are in a position to say 
that the convoy was attacked." (Borger and Ackerman 2016b) That is, while the U.S. confidently accuses Russia of having committed an airstrike - and the media follow suit, the UN states that there is no evidence that the attack was an airstrike to begin with, let alone a Russian one. Ironically, this clarification, which reveals that the U.S. American claims are fundamentally unfounded, is quoted under all of the aforementioned headlines by The Guardian, The Independent, or The Daily Mail. In short, these news outlets elevate to a prominent - headline - position a claim that is shown, in the very same articles, to have no factual basis whatsoever. Nevertheless, none of the articles allows Laerke's statement to break the overall impression of definite Russian guilt. He receives, besides the quotation itself, only one introductory sentence by The Guardian and two sentences, with the same content, by The Daily Mail, for instance. Amidst the flood of empty accusations and assumptions, the reader inevitably loses sight of the one piece of information which puts the story into perspective.

Also, on 5 October 2016, the United Nations released the findings of an internal investigation of the attack. Lars Bromley, a UN Operational Satellite Application Programme (UNOSAT) research adviser, is quoted by all major news organisations as saying: "With our analysis we determined it was an air strike and I think multiple other sources have said that as well." (BBC 2016; Dearden 2016; Nebehay 2016) However, Bromley immediately contradicts his own statement by saying that the damage was caused "almost certainly [by] airdropped munitions" [my emphasis] (Nebehay 2016); that is, nothing has, in fact, been "determined". Significantly, his latter statement is quoted in none of the news articles, except for the one by Reuters. After Bromley's assertion of definitive conclusions, however, another UNOSAT official, Einar Bjorgo, goes to correct him in an interview with Renters saying that the "observations of the imagery show indications of it possibly being an air strike, [so] we believe it may be air strikes, but it's not conclusive." [my emphases] (Nebehay 2016) Note the abundance of words, in italics, expressing uncertainty, rendering the sentence barely meaningful anymore. In this case, there are two 'equals' as contesting sources. Nevertheless, the articles covering the report, without exception, appear with headlines similar to the $B B C$ 's "Syria conflict: Aid convoy attack was air strike, UN expert says", or Renters' "Aleppo aid convoy hit by air strike: U.N. expert". Thus, Bromley's claim is unanimously embraced despite clear knowledge that it is false: With the exception of The Independent, which omits Bjorgo's statements entirely, both Bromley and Bjorgo are directly quoted in the articles by the BBC, The Guardian, The Daily Mail, or Reuters, for instance. Also, note that Bjorgo, unlike Bromley, is not referred to as an expert, which falsely indicates a professional hierarchy between the two. The emphasis and insistence on Bromley's claim provides a faux impression of closure, confirmation, and comfort that the favourable narrative has been the correct one all along, while, in fact, there have been no new developments and no more is known than before - a condition which is, admittedly, much less attractive to report than the illusion of knowledge, truthfulness aside. 


\subsection{The Requirements of Expertise}

Although there are numerous references to experts, who reportedly refute or dismiss certain claims while confirming others, there is very little discussion about who they actually are and why they are considered experts in the first place. Even if these individuals or organisations are named, there are rarely any details or explanations given as to their expertise, professional background, or potential limitations. Interestingly, it is regularly pointed out that these organisations are not Syria-based, still there is not a single remark even implying the possibility that this factor may have negative consequences. For instance, one of the most prominent analysts and sources of information on the Syrian conflict, the Syrian Observatory for Human Rights (SOHR), despite its organisational-sounding name, is essentially one person, Rami Abdulrahman, reporting from his apartment in Coventry (Abbas 2011). He is admittedly pro-regime-change in Syria (ibid.), and, despite claiming to be unaffiliated with political bodies, receives funding from the British Foreign Office (Media Lens 2018). The previously mentioned White Helmets are funded by numerous Western governments as well as the Gulf monarchies, such as Qatar (Beeley 2017, 215t Century Wire 2016; 2017), work closely and exclusively with, and are often members of, 'rebel' groups, most notably al-Nusra Front, the Syrian branch of al-Qaeda (Bartlett 2018; Beeley 2017; Le Corf 2017), and have repeatedly been caught manipulating or manufacturing evidence (Bartlett 2018; Beeley 2018). Bellingcat, a UK-based open data analysis organisation, admittedly relies on "news agency pictures and pictures taken by rescue workers" (McKernan 2016), predominantly the aforementioned White Helmets. Lastly, UNOSAT "reviews only commercially available satellite images." [my emphasis] (Nebehay 2016) Nevertheless, the seemingly obvious question is not once asked: How reliable can they be when they clearly take sides in the conflict, rely on that side for financial, material, and ideological support and only have access to a fraction of the data 'out there', and even those are second-hand data at best, coming from organisations with a clear agenda of their own?

Discussions about the attack were revived when Bellingcat managed to "match debris [on site] to Russian-manufactured munitions" (McKernan 2016), namely the remnants of an OFAB 250-270 fragmentation bomb. Critiques, however, countered by "pointing out that the debris might not necessarily date from the aid convoy attack, or been [sic] planted there, or that the pictures are fake." (ibid.) While the news media at large dismiss these as nothing more than "absurd" suppositions or conspiracy theories "typical of pro-Kremlin social media commentators" (ibid.) - which is expected to serve the purpose of a refutation - they have, in fact, very real substance. First of all, Bellingcat can never be certain about authenticity when working with second- or third-hand material. In fact, it was Bellingcat itself who had 'proved' that Russia had manipulated the released satellite images of the Malaysia Airlines case in Ukraine, so they must be familiar with the potential dangers of relying on mediated data. Secondly, as the photographs analysed had not been taken immediately after the attack (the attack took place at night, while the photographs were taken in broad daylight), it is impossible to tell for certain 
whether or not the remnants had indeed been planted there subsequently. Moreover, as mentioned before, the rescue workers, who provided the photographs and recordings, are financially and ideologically tied to the West, and do have a history of staging, falsifying, or eliminating evidence. Bellingcat makes hasty conclusions by singling out one item that confirms the dominant, desirable theory, while dismissing the environment and other indicators, which happen to contradict the promoted story.

What is striking in the news coverage of Bellingcat's analyses is that the reliability of the organisation is never questioned. Regardless of how much The Independent compliments Bellingcat as "self-taught open data experts and citizen journalists" (McKernan 2016), they have no more professional background than their counterparts discredited as "social media commentators" and "bloggers" (ibid.) - a term that has been applied to Bellingcat by professional experts (Bidder 2015). For instance, in relation to their supposed proof of Russian manipulation of satellite images, German forensic expert Jens Kriese expressed criticism in an interview with Der Spiegel, saying that the method Bellingcat had used (Error Level Analysis) is necessarily "subjective and not based entirely on science", "is a method used by hobbyists", and "doesn't prove anything." (ibid.) Even the creator of the tool the organisation used, Neal Krawetz, distanced himself from Bellingcat's claims and remarked that it was an excellent example of "how to not do image analysis." (ibid.) Despite an apparent lack of competence and of a professional scientific approach, however, the group is still introduced as "well regarded for their work" (McKernan 2016); their trustworthiness and reliability are taken for granted and they remain a prominent source of analyses concerning the Syrian conflict. In short, knowledgeability and expertise are determined not based on professionality but based on affiliations - the prerequisite for being considered an expert is the confirmation of the ideologically useful narrative (Herman and Chomsky 1988, 23).

\section{Conclusion}

As this paper has sought to demonstrate, the keyword here is illusion. As opposed to centralised media, corporate media manage to maintain the illusion of independence and the illusion of objectivity and factuality. This is exactly why it is much more difficult to recognise ideologies or bias in corporate news - they work in a significantly more subtle way and thus usually pass unnoticed. Instead of explicitly telling the audience what to think, such a system rather aims at influencing how the public will think, and about which issues. (van Dijk 1988a, 208) Thus, the reader will likely arrive at the 'desired conclusion' by their own 'free' thinking, either unaware of or unconcerned by the ideologies and agendas hidden behind the façade of the 'free press'. As seen from the examples, the key to the success of news discourse in directing public views and thinking is unconditional trust and uncritical reading. Therefore, it is necessary to adopt a critical approach to news consumption, regardless of where it comes from, 
in order to resist the manipulative influence of biased, ideologically charged, and often misinformed or uninformed news content.

It is, therefore, indispensable for both the reader and the reporter or journalist to acknowledge that one "is only a small part of the world, that [one's] intelligence catches at best only phases and aspects in a coarse net of ideas" (Lippmann 1922, 68), and to act accordingly. It is only then that "when we use our stereotypes, we tend to know that they are only stereotypes, to hold them lightly, to modify them gladly.” (ibid.) Such awareness and openness for self-correction is the essence of intellectual growth and cultural learning. Moreover, the prerequisite for a propaganda system to remain effective is that the vast majority of the population, for whatever reason, cling to the comfort of conformism. The media essentially count on what Lippmann, Bernays, and others call the 'herd mentality' of the population, (Bernays 1928; Fowler 1991, 232; Lippmann 1922) and on public "consent to domination" (Wetherell and Potter 1992, 85). It follows that, in a truly democratic society, the effectiveness of manipulation is undermined as soon as the public engages in critical reading and thinking (Fowler 1991, 232). The solution lies in the exposure to alternative, dissenting, and often contradicting perspectives. They provide additional aspects of and insights into the issues in question. It is important for the public not to adopt the 'competition narrative' of media organisations, which encourages an either/or view. On the contrary, various sources of news need to be seen in terms of mutual complementation, where exposure to as many distinct points of view as possible is encouraged instead of the rejection of all but one's own.

In order to avoid implying that all the burden, not to mention blame, is on the public, however, I would like to end with a note to intellectuals in general, and journalists in particular. In many respects, the current distrust in the media and in the so-called 'liberal' intellectuals is a result of their failure to connect with the public. Yet the very same people and organisations responsible for this alienation, instead of engaging in selfexamination, blame their losses on the victims: the public. Dominant 'liberal' voices, be they the media, politicians, entertainers, or commentators, have embraced a form of patronising, holier-than-thou attitude towards the population. Most worrying of all, perhaps, is that they have adopted the approach - traditionally associated with, though certainly not limited to, the right-wing - of throwing in unsubstantiated claims with no evidence and argumentation, hoping that constant repetition would eventually suffice. Mainstream news reporters and journalists have become so far detached from the public, so unaccustomed to debates that they are often unable to handle a situation when they are questioned or simply have to explain themselves. It is, however, indispensable for intellectuals to be able to engage in and deal with situations where not everyone is only nodding in agreement and acceptance. They need to re-connect with the public through discussion and debate, and to serve a truly informational and educational purpose, while themselves being open for learning and self-correction. The purpose of news-making and journalism should not be to serve the establishment, thus reproducing the existing power structures, nor to provide comfort. Instead, it should ideally 
be the exact opposite: To raise questions, to also reflect on systemic shortcomings, to investigate, and to question authorities and the establishment, whether or not they are 'our' own and regardless of how discomforting the revelations may be - a task which, as demonstrated in this paper, corporate news media have utterly failed to fulfil.

\section{References}

$21^{\text {st }}$ Century Wire. "White Helmets Funded By US, UK, EU and Qatar Governments." $21^{\text {st }}$ Century Wire, October 10, 2016. Accessed June 6, 2018. http://21stcenturywire.com/2016/10/10/ white-helmets-funded-by-us-uk-eu-and-qatari-governments/.

$21^{\text {st }}$ Century Wire. "Secret $£ 1$ bn UK War Chest Used to Fund the White Helmets and Other 'Initiatives'." 21 $1^{\text {st }}$ Century Wire, March 13, 2017. Accessed June 6, 2018. http://21stcenturywire. com/2017/03/13/secret-1bn-uk-war-chest-used-to-fund-the-white-helmets-and-other-initiatives/.

Abbas, Mohammed. "Coventry - An Unlikely Home to Prominent Syria Activist." Reuters, December 8, 2011. Accessed June 6, 2018. https://uk.reuters.com/article/uk-britain-syria/coven try-an-unlikely-home-to-prominent-syria-activist-idUKTRE7B71XG20111208.

Barrett, Richard. 2014. Foreign Fighters in Syria. New York: The Soufan Group.

Bartlett, Eva. "How the Mainstream Media Whitewashed Al-Qaeda and the White Helmets in Syria." Global Research, January 6, 2018. https://www.globalresearch.ca/how-the-mainstreammedia-whitewashed-al-qaeda-and-the-white-helmets-in-syria/5624930.

BBC. "Syria Conflict: Aid Convoy Attack Was Air Strike: UN Expert Says." BBC, October 5, 2016. Accessed June 6, 2018. https://www.bbc.com/news/world-middle-east-37561755.

Beeley, Vanessa. "Investigation: White Helmets Committing Acts of Terror Across Syria." Mint Press News, September 6, 2017. Accessed June 6, 2018. https://www.mintpressnews.com/investi gation-white-helmets-committing-acts-terror-across-syria/231597/.

Beeley, Vanessa. "White Helmets Exploit Children to 'Manufacture Consent' for 'Humanitarian' War in Syria." $21^{\text {st }}$ Century Wire, March 6, 2018. http://21stcenturywire.com/2018/03/06/whi te-helmets-exploit-children-manufacture-consent-humanitarian-war-syria/.

Bernays, Edward. 1928. Propaganda. Brooklyn, New York: Ig Publishing.

Bidder, Benjamin. "Expert Criticizes Allegations of Russian MH17 Manipulation.” Der Spiegel, June 4, 2015. Accessed June 6, 2018. http://www.spiegel.de/international/world/expertcriticizes-allegations-of-russian-mh17-manipulation-a-1037125.html

Borger, Julian, and Spencer Ackerman. "Russian Planes Dropped Bombs that Destroyed UN Aid Convoy, US Officials Say.” The Guardian, September 21, 2016a. Accessed June 6, 2018. https://www.theguardian.com/world/2016/sep/20/un-aid-convoy-attack-syria-us-russia

Borger, Julian, and Spencer Ackerman. "Ban Ki-Moon Condemns 'Apparently Deliberate' Syria Aid Convoy Attack.” The Guardian, September 20, 2016b. Accessed June 6, 2018. https://www. theguardian.com/world/2016/sep/20/un-suspends-all-aid-convoy-movements-in-syria-after-air strike

Chomsky, Noam. 1989. Necessary Illusions. London: Pluto Press.

Chomsky, Noam. 2016. Who Rules the World?. Toronto: Hamish Hamilton.

Chulov, Martin, and Kareem Shaheen. "Syria Aid Convoy Attack: 'The Bombardment Was Continuous'.” The Guardian, September 21, 2016. Accessed June 6, 2018. https://www.theguardian. 
com/world/2016/sep/20/the-bombardment-was-continuous-the-rescue-teams-werent-even-ableto-work

Dearden, Lizzie. "Russian 'Experts' Claim Aleppo Aid Convoy Attack Was 'Staged Hoax' After UN Releases Satellite Images of Air Strikes.” The Independent, October 5, 2016. Accessed June 6, 2018. https://www.independent.co.uk/news/world/middle-east/aleppo-aid-convoy-attacksyria-russian-un-satellite-data-confirms-that-air-strike-killed-20-aid-a7345601.html

Dunford, Joseph F. In "Hearing to Receive Testimony on U.S. National Security Challenges and Ongoing Military Operations" by Committee on Armed Services. Washington, D.C.: Alderson Court Reporting. September 22, 2016. Accessed 15 June, 2017. http://www.armedservices.senate.gov/imo/media/doc/16-71_09-22-16.pdf

Fowler, Roger. 1991. Language in the News. New York: Routledge.

Freedman, Des. 2014. The Contradictions of Media Power. London: Bloomsbury Publishing Plc.

Goodall, Heather, et al. 1994. Racism, Ethnicity and the Media, edited by Andrew Jakubowicz. St. Leonards, Australia: Allen and Unwin Pry Ltd.

Herman, Edward S., and Noam Chomsky. 1988. Manufacturing Consent. New York: Pantheon Books.

McKernan, Bethan. "Aleppo Aid Convoy Attack: Russian Bomb Remains 'Recovered From Site'." The Independent, September 23, 2016. Accessed June 6, 2018. https://www.independent. co.uk/news/world/middle-east/aleppo-aid-convoy-attack-russian-bomb-remains-recovered-fro m-site-a7324841.html

Media Lens. "The Syrian Observatory - Funded By The Foreign Office.” Media Lens, June 4, 2018. Accessed June 6, 2018. http://www.medialens.org/index.php/alerts/alert-archive/2018/872the-syrian-observatory-funded-by-the-foreign-office.html

Nebehay, Stephanie. "Aleppo Aid Convoy Hit by Air Strike: U.N. Expert." Reuters, October 5, 2016. Accessed June 6, 2018. https://www.reuters.com/article/us-mideast-crisis-syriaconvoy/aleppo-aid-convoy-hit-by-air-strike-u-n-expert-idUSKCN1250QF

Lippmann, Walter. 1922. Public Opinion. New York: Penguin Books.

Le Corf, Pierre. "Le Corf: White Helmets Were Al-Qaeda's Next Door Neighbours In Aleppo." $21^{\text {st }}$ Century Wire, March 15, 2017. Accessed June 6, 2018. http://21stcenturywire.com/2017/ 03/15/le-corf-white-helmets-were-al-qaedas-next-door-neighbors-in-aleppo/

Robinson, Julian, and Jennifer Newton. "Moscow Claims Drone Footage Shows Syrian 'Militants' Travelling with UN Aid Convoy as Cover Moments Before Trucks Exploded as it Denies Claims They Carried Out Air Strike.” The Daily Mail, September 21, 2016. Accessed June 6, 2018. http://www.dailymail.co.uk/news/article-3799699/Russia-carried-air-strike-Syrian-aidconvoy-REVENGE-forces-bombing-Assad-s-troops.html

Shiraz, Sheeffah. "Fighting for Freedom: The Syria Campaign." The New Arab, March 14, 2016. Accessed June 6, 2016. https://www.alaraby.co.uk/english/indepth/2016/3/14/fighting-forfreedom-the-syria-campaign

Stewart, Phil, and James Dalgleish. "Russian Jets Carried Out Strike on Syria Aid Convoy: U.S. Officials.” Reuters, September 20, 2016. Accessed June 6, 2018. https://www.reuters.com/arti cle/us-mideast-crisis-syria-intelligence/russian-jets-carried-out-strike-on-syria-aid-convoy-u-s-off icials-idUSKCN11Q2PR

van Dijk, Teun A. 1988a. Neres Analysis. Hillsdale, New Jersey: Lawrence Erlbaum Associates, Publishers. 
van Dijk, Teun A. 1988b. Nerws as Discourse. Hillsdale, New Jersey: Lawrence Erlbaum Associates, Publishers.

van Dijk, Teun A. 1991. Racism and the Press. London: Routledge.

van Dijk, Teun A. 1993. Elite Discourse and Racism. Newbury Park, California: SAGE Publications, Inc.

Walker, Tim, and Bethan McKernan. "US Claims Russian Warplanes Bombed Syrian Arab Red Crescent Aid Convoy and Warehouse." The Independent, September 20, 2016. Accessed June 6, 2018. https://www.independent.co.uk/news/world/us-claims-russian-warplanes-bombedsyrian-arab-red-crescent-aid-convoy-and-warehouse-a7319521.html

Wetherell, Margaret, and Jonathan Potter. 1992. Mapping the Language of Racism. London: Harvester Wheatsheaf.

Zima, Peter Václav. 1989. Ideologie und Theorie. Tübingen: Francke Publisher, Inc. 